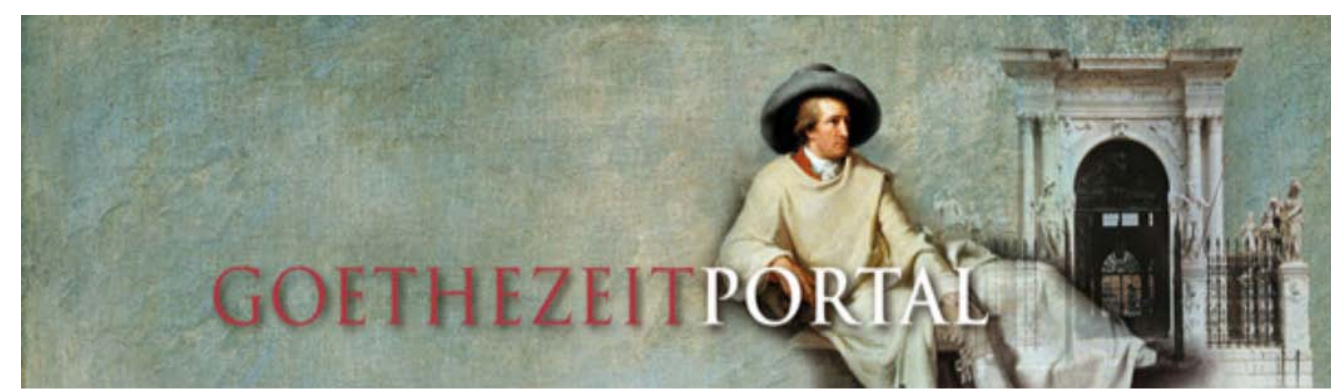

FORUM: Postkoloniale Arbeiten / Postcolonial Studies

\title{
Cultural translation: a value or a tool? Let's start with Gramsci!
}

\author{
BIRGIT WAGNER (University of Vienna)
}

I have done recently some work on Homi Bhabha's concept of cultural translation which has led me to a critical vision of the author's proposals (Wagner 2008). What I am doing in this paper is a continuation of this critical review and, at the same time, a genealogical approach to the topic. ${ }^{1}$

'Cultural translation' is a catchword we may find in many different contexts: in publicity material for scientific journals and courses of study of business schools as well as in such renowned theory like that of Homi K. Bhabha (1994), while other critics like Gayatri Chakravorty Spivak (2007) speak of "translation as culture”. The sometimes inflationary use of the t-word inside and outside of academia can raise suspicion, especially if we consider that it is always proposed as a positive phenomenon, even a value or a political remedy to the ills of globalization. Theoreticians like the German literary studies scholar Doris BachmannMedick (2006, 2009), who has done a lot of work on the topic, consider even the possibility of a worldwide "translational turn" which she believes to possess a critical potential when it comes to dealing with the impacts of globalization. But before we follow this jumping to conclusions, it is wise to do some genealogical work on the metaphorical uses of the term 'translation' in the past, hoping to gain a critical point of view on the term's present uses and abuses.

Most recent publications that deal with the promises of a supposedly new translating culture quote Benjamin's famous essay on translation (The Task of the Translator, first published in German in 1923; Benjamin 1991), sometimes without reflecting the fact that

\footnotetext{
${ }^{1}$ A first version of this essay has been presented at the conference "Dialogue \& Difference. Mediations on Local / Global Values in Postmodernity” of the SOAS (School of Oriental and African Studies, University of London), organized by Cosimo Zene in 2009; the second version at the International Conference Translatio/n. Narration, Media and the Staging of Differences, organized by the Institut für Kulturwissenschaften of the Austrian Academy of Sciences (2010, organizers: Michael Rössner and Federico Italiano).
} 
Benjamin talks about translation on the literal level, that is interlingual translation, and not about transfer processes ‘between’ cultures however you might figure them in a concrete way. So whereas Benjamin's essay seldom fails to be quoted, another name does not show up in the international discussion: that of Antonio Gramsci. Even in the field of Gramsci scholarship, it is only recently that attention has been dedicated to the philosopher's activities as translator and his thoughts on translatability. A founding text in this field is the accurate analysis by Derek Boothman (2004a), a text however that might be known only to Gramsci scholars, which may also be the case for the book dealing with the same topic (2004b) the author published with a small Italian publisher. Linguistic frontiers may also limit the number of readers of Giorgio Baratta's most interesting study Antonio Gramsci in contrappunto. Dialoghi col presente (2007), a book in which the Gramscian term 'translatability' is a recurrent leitmotif. At any rate, this new attention to an unexplored aspect of Gramsci's work has not yet made its way to the international discussion on translation processes.

So it may be interesting to trace the idea - not the term - of cultural translation back to Gramsci and consider its relation to more recent debates. Can Gramsci’s insights, born in loneliness and beyond any theory hype, help us to see if 'cultural translation' is a valuable candidate to the list of 'universal values'? Or is it rather a tool that may be used for diverse purposes?

\section{"Is there a language that can ever be translated exactly in another?" Gramsci as a translator}

In his Prison Notebooks, Gramsci does not use the term 'cultural translation'. He speaks of 'translation' (of languages and of what we nowadays call discourses, cultures and subcultures), and he discusses the notion of traducibilità (translatability). In Valentino Gerratana’s rightly famous critical edition of the Prison Notebooks (Gramsci 1975), neither of the terms can be found in the index rerum (indice per argomenti), an index that fills more than a hundred pages! This shows clearly that the t-word was not considered of any interest up to the middle of the seventies of the past century. Two reasons can be given to explain this lack of interest. In his opening statement to a special edition of the journal Lares (May-August 2008), Giorgio Baratta provides a useful period-scheme of Gramsci scholarship inside and outside Italy. He emphasizes that by that time Gramsci was considered in Italy mainly a national author, a political guide in the ideological struggles of the post-war decades, a tutelary figure that could be appropriated differently by the various wings of the Italian left. We know on the other hand that translation studies and the hype of 'cultural translation' came 
up only in the eighties and nineties respectively, both related to the new political and intellectual interests raised by postcolonial studies (a short history of the young discipline of translational studies in the English speaking world is provided by Trivedi 2007).

Anyway, why should we want to turn back to Gramsci while many other specialists seem to be more competent for the question? First, it seems correct to highlight his status as a precursor to a new and successful academic discipline; second, Gramsci is certainly an authority in discussing political values. Boothman (2004a) underlines the fact that the philosopher's thoughts on the topic are raised by his dealing with as different philosophical schools as Marxist tradition, German idealism and Croce's elaboration of both (a field of study embracing different languages and national cultures, including the French). As convincing as this is, my claim is that Gramsci's attention for translatability of discourses and cultures has its most profound roots in his early every day-experience of differences: as a member of a minority culture - he was born and raised in Sardinia, a very peculiar region of Italy with its own history and an indigenous language, hence providing him an early experience of bilinguism - and as a politician who was well aware not only of class differences but also of regional or national mentalities and cultures. He discusses linguistic and cultural differences as sources of misunderstanding in various parts of the Prison Notebooks and, in a more personal way, in his letters to his Sardinian family, his Russian wife Julka, and his sister-in-law Tania. In a significant text about Kant's universal concepts in ethics that I will discuss later, Gramsci comes to define tentatively what is his theoretical offer to bridge the gap between the 'universal' and the 'local', in terms of values, and to define the status of what we use to call 'cultural translation'.

Before I start to discuss this line of argument mostly found in the $10^{\text {th }}$ and $11^{\text {th }}$ of his Prison Notebooks, but subliminally or overtly present in many other sections, it may be useful to consider what translation - on its first and non-metaphorical level - meant to Gramsci. He was well aware of the main difficulty any translator encounters: "translation is necessary but impossible”, as Spivak (2007, p. 261) puts it. In his more sober way Gramsci (1975, p. 1450) asks: "Is there a language that can ever be translated exactly in another? Is there a single word that can ever be translated exactly in another language?”2 Nevertheless this awareness of an inevitable aporia does not discourage him to give translation a try. As a matter of fact, in the endless hours he has to spend in prison, one of his intellectual training tools is translating Russian and German texts into Italian. It is only in February 1929 that Gramsci is allowed by

\footnotetext{
${ }^{2}$ Given the unfinished state of Joseph Buttigieg's critical edition and translation of the Prison Notebooks (Columbia University Press, 3 volumes published), I prefer to translate all quotations of Gramsci's works myself, giving the Italian text in the notes whenever this seems helpful.
} 
the prison authorities to write not only letters, but notes for his own use - he had been arrested in November 1926 -, and the first task he sets about is translation: to "get some practice", as he writes to his sister-in-law Tania (Gramsci 1975b, p. 253), and to compensate what he feels as "the lack of expressive modes for modernity" of the Italian language, as he puts it in a letter to Julka (ibid, p. 256).

The study of these "exercises", as he called them, has been recently facilitated by the publication of the first two volumes of the new edizione nazionale of his work, promoted by the Fondazione Istituto Gramsci. This currently unfinished editorial project started with the publication of the "translation notebooks" (Quaderni di traduzioni) which were only in a very small part available in Gerratana's edition. Now we can read all the texts translated by Gramsci: seven hundred pages in the manuscript, as Giuseppe Cospito, one of the editors, states (in: Gramsci 2007, p 13).

Even considering that Gramsci's choice of texts to translate was determined by his condition as a prisoner of fascist Italy and the restricted access to books this implied, it is fascinating to see the authors and topics he chose to exercise his mind, as a survey on the table of translated texts indicates: a 1927 special edition of a German journal on the then new American literature, a significant choice of Grimm's Fairy Tales, a book on linguistics, an anthology of Russian literature, poetry of Goethe (for which he gave a prose version), some of Goethe's conversations with Eckermann as well as a choice of texts by Marx, figuring in Wage-Labour and Capital (Lohnarbeit und Kapital).

Not surprisingly, all these texts are in one way or another related to the topics treated in the Prison Notebooks. Fascinating as this is, more interesting for my purpose is the question what kind of translator Gramsci turns out to be. The problem has been studied by the German Studies specialist Lucia Borghese (1981), and more recently by the editors of the edizione nazionale. Apart from the fact that Gramsci did not possess the linguistic competence required for a professional translator and had only poor reference books at his disposal, he chose significant translation strategies that may be linked to his meditations on translatability of cultures that emerge soon after the "translating period" of Gramsci's time in prison. ${ }^{3}$ It seems that his strategies varied according to the literary form and the content of the source-texts. He worked hard on the form when dealing with aesthetically challenging texts, say Goethe, but also Grimm's Fairy Tales. However, he felt bound to the ideal of fidelity in the case of the book on linguistics, but felt free to give his own version on other texts which in his mind had to be "culturally" translated, that is, adapted to the horizon of a special

\footnotetext{
${ }^{3}$ Boothman (2004a, 2004b) discusses the genealogical development of the topic from the first to the latest occurrence as well as the rewriting processes (texts A and C in the classification of Gramsci scholarship).
} 
community of readers. Let me give two examples. He planned to send his version of Grimm's tales to the children of his sister Teresina (a project that never could be realized because it was not permitted by the prison authorities), and consequently he tried to adapt the texts to the rural Sardinian universe these children experienced, not to mention the fact that he eliminated terms related to a Christian conception of the world in order to give them a "laic version". In the case of Marx, according to Giuseppe Cospito, the author of the introduction to the translation notebooks, it is more the choice of texts - a personal and philosophical interest that contradicts the Marxist orthodoxy of his time - than the translation strategies that matter. As Cospito (in: Gramsci 2007, p. 32) puts it, Gramsci as translator displays strategies that open up possibilities ranging from literality to interpretation and sometimes to theoretical (that is, in his case, political) use.

What can be deduced from this rough survey? Even when doing “exercises”, meant to train his mind and keep him occupied while in prison, Gramsci never forgets the finality of any text: to reach the reader, to have an impact on the reader's common sense, to "educate" the reader's common sense. In order to do so, the text has to anticipate the reader's intellectual horizon and her possible reading habits. Arguably, this is an attitude that encourages cultural translation. I will however stress later that there is more at stake than merely an adaptation to the reader's mental habits.

\section{Crossing metaphorical thresholds}

First, let me make another crucial distinction. What happens when we pass the metaphorical threshold that divides translation from cultural translation? Translation deals with natural languages and their differences anchored in the significants - language's material support and on the semantic or cultural level. Boris Buden and Stefan Nowotny (2009), in their programmatic essay that features in one of the latest issues of the journal Translation Studies, claim that interlingual translation "always already” implies a form of cultural translation, putting forward valuable arguments for their thesis. But even so, interlingual translation is another activity - another practice - than cultural translation; it is essentially bound to language. The very term of cultural translation is a metaphor: and any term undergoes a process of shifting its meaning when promoted to a metaphor, and all the more so when the term has experienced a brilliant career as a "travelling concept" (Bal 2000) between the disciplines of academic research. Several of the responses to Buden and Nowotny's essay, published in Translation Studies 2/2 and 3/1, insist on this point and discuss the lack of conceptual clarity inherent to the metaphorical use of the term translation. 
What can cultural translation anyway designate? Referring to that term, we no longer talk about the passage from one natural language to another, we talk about a transfer process that implies linguistic and extra-linguistic phenomena like media-bound representations, values, patterns of thinking and modes of behaving, in other words: various kinds of practices that travel from one cultural context to another and by doing so undergo processes of meaning-shifting, or rather: of an extension of meaning, insofar they acquire a double meaning. As Paul St-Pierre (2007, p. 5) convincingly states, every form of translation designates not only its "referent", but also the fact that it is a translation and as such marked by alterity.

Getting back to Gramsci, before I venture to propose a hypothesis about what might have been his notion of cultural translation, it is the notion of translatability (the notion that occurs in Gramsci's texts) that has first to be elucidated. Giorgio Baratta, the Italian philosopher who dedicated much of his attention to Gramsci, states that the Sardinian philosopher takes his readers to "rethink dialectics in the light of translatability: translatability of languages and cultures.” (Baratta 2008, p. 22, my translation). The notion of translatability is thus to be understood as a "rethinking of dialectics" (ibid.), and that is, as the author explains, as an overcoming of the universalizing tendencies of the European philosophical concept of dialectics. Relying on the postcolonial discourse inaugurated by Edward Said, Baratta offers an interpretation that develops Gramsci's insights to a discursive tool that should allow transcending Eurocentric thought and acting. According to Baratta, Gramsci's philosophical and political heritage is to be situated in the uncertain space "between dialectic (contradiction) and translatability (difference)” (ibid., p. 23). I must emphasize the connection Baratta establishes between the terms translatability and difference: difference is, among others, a central notion to postcolonial studies, difference as a process never concluded, always produced in discursive acts and never 'given' as a natural fact. Difference can be considered the limit of translatability in as much as a word, or a value, or a pattern of behaving will remain 'other', that is: marked when introduced in another context. At the same time, difference is the source of richness that translation processes provide: they allow to acknowledge, embrace, enjoy, but also to reject and fear differences. Thinking about translatability may offer the possibility to consider difference a richness of our world (in the sense that it provides variety), but also offer the means how to communicate difference in a peaceful and respectful way. The latter is what I call the political hope of the tenants of the ‘translational turn’ (to quote again Bachmann-Medick). 


\section{Gramsci on translatability}

At this point, let us examine what Gramsci has to say about the topic, even if the term we use nowadays does not occur in his texts. Translatability, the term he actually uses, is not a synonym of cultural translation, but it gets close to it. In what follows I do not intend to provide an exhaustive analysis of the occurrences of the term in the Prison Notebooks - this has been done by Boothman, whose admirably accurate work serves as a background for my essay - I rather wish to draw the attention to a few passages, some of them seldom analysed, which can be articulated with current debates.

In the $11^{\text {th }}$ notebook called Introduction to the Study of Philosophy ${ }^{4}$ Gramsci remembers a remark made by Lenin where the Soviet leader mourns a lost occasion in international politics. Lenin actually talks about the Third International Congress of Communists (1921), and he criticizes the fact that the final resolution paper "did not succeed to 'translate' our [Russian, B.W.] language in the other European languages” (Gramsci 1975a, p. 1468) ${ }^{5}$ - I quote this sentence in the form Gramsci remembered and wrote down without having Lenin's text at his disposal. Why did he remember exactly this passage, why was it important to him? To answer that question, the reader has to refer to the section's headline: “Translatability of scientific and philosophical languages” (ibid.) ${ }^{6}$. So we may suppose that according to Gramsci, Lenin did not wish to question the professionalism of the translators of the resolution; he did not refer to the question of literal translation. Lenin criticized the fact that when the paper was drafted, the question of what we call interdiscursive and/or cultural translation had been neglected: so, a resolution that had been written by the standards of 'Russian' Soviet conventions had little chances to be rightly understood by the addressees who would not share this particular mentality, readers to whom the paper, as a matter of fact, had been dedicated. Let us put it in other terms: a person, or a political entity, who does not take into account the 'translatability' of his or her discourse will not be able to achieve political goals. This short note on a passage of Lenin shows us time and again to what degree Gramsci possessed the capability to develop his insights starting from an apparently isolated detail or a singular quotation: exactly what he used to call his method or in other words "living philology" (filologia vivente).

Lenin's observation that Gramsci remembers allows him to address what he considers the political necessity of cultural translation. In the following paragraph of the same notebook, he talks about the "mutual translatability of the various philosophical and academic

\footnotetext{
4 “Introduzione allo studio della filosofia”.

5 “non aveva saputo ‘tradurre’ nelle lingue europee la nostra lingua”.

6 “Traducibilità dei linguaggi scientifici e filosofici”.
} 
languages” (ibid.) ${ }^{7}$ - the translatability of discourses related to different disciplines and paradigms, as we would put it today. For Gramsci, this is however a problem that transcends the limits of academia. If we think historically as he constantly invites us to do, the problem is to be addressed in a broader sense and acquires greater importance. It leads to the following two questions:

First, how do we figure translatability between civilizations which may consider themselves different, but are "fundamentally" on the same level (ibid.) ${ }^{8}$ and second, the question "if translatability is possible between the manifestations of different cultural phases" (ibid.) ${ }^{9}$. On behalf of this second point, Gramsci may have thought of - as the context of the paragraph and the whole $11^{\text {th }}$ notebook suggests - the difficulty to 'translate' the language of Marxism to not specially trained auditors, but my claim is again that he came up with this problem because he had in mind his experience of a very special relationship, namely that of the Sardinian culture of his time with the 'national' Italian culture. And arguably he thinks about this relationship in terms of phase displacements, in terms of differences, and the hierarchical relations between the two - both topics he addresses theoretically in the notebooks dedicated to "folklore" and in the letters to his Sardinian family members. For him, translatability means also the political task to communicate with people who do not share the "philosophical and academic language" of the political leaders. So these leaders are summoned to avoid what Gramsci defines the "philosophical and academic Esperanto" (Gramsci 1975a, p. 1467) ${ }^{10}$, that is, a stereotyped jargon which tends to fossilization and consequently to political inefficiency. On this occasion, he comes up with an interesting rhetorical figure, a similarity: "One could say that [...] the mental attitude that primitive peoples adopted confronting others they encountered, is still surviving. Each primitive people called (or calls) itself with a name that signifies also 'man' and the others with words that signify 'dumb’ or 'stammerer' (barbarians) insofar as they don’t know 'the language of men' [...]. For the philosophical or scientific Esperanto-speakers, everything that cannot be expressed in their language is delirium, prejudice, superstition etc.” (ibid., p. 1466/67) ${ }^{11}$ So what the academic Esperanto-speakers of his time do (and partly still are doing) is, according

\footnotetext{
7 “Traducibilità reciproca dei vari linguaggi filosofici e scientifici“.

8 “espressione culturale 'fondamentalmente' identica, anche se il linguaggio è storicamente diverso, determinato dalla particolare tradizione [...]”.

9 “tra espressioni di fasi diverse di civiltà".

10 "Esperanto filosofico e scientifico”, headline to $\S 45$, the one which precedes the section “Translatability of scientific and philosophical languages”.

11 “Si può dire che si sia perpetuato [...] lo stato d'animo dei popoli primitivi verso gli altri popoli con cui entravano in rapporto. Ogni popolo primitivo chiamava (o chiama) se stesso con una parola che significa anche ‘uomo' e gli altri con parole ce significano ‘muti' o ‘balbettanti' (barbari), in quanto non conoscono la 'lingua degli uomini' [...]. Per gli esperantisti della filosofia e della scienza tutto ciò che non è espresso nel loro linguaggio è delirio, è pregiudizio, è superstizione, ecc.”
} 
to Gramsci, the expression of a primitive attitude which does not take into account the necessity of translation. One could think, in that case, of the term 'mediation', but translation seems more adequate, as it refers to a process of "saying something" in "another way of saying the same thing” (St. Pierre 2007, p. 5) - be it an intralingual or interlingual transfer act.

At this point, it may have become clear what "translation” in the metaphorical sense means for Gramsci: a communication process, or a dialogue which not only keeps in mind the communicative habits of the addressees - this would reduce translation to pure didactics - but which also respects the conception of the world, the common sense and the mentality of the interlocutors who are not mere listeners but may have something of their own to say. Gramsci calls this attitude in a famous passage of his Notebooks empathy (con-passionalità, 1975a, p. 1430). ${ }^{12}$ It is an attitude of sharing and not, as Homi K. Bhabha would have it for his understanding of cultural translation, a synonym of the staging of difference.

In the same $11^{\text {th }}$ notebook we finally encounter the paragraph which seems to me the counterpoint ${ }^{13}$ to the reflections on the translatability of languages and discourses. The headline to it is Ethics, and Gramsci examines the famous Kantian imperative: “Act only according to that maxim whereby you can at the same time will that it should become a universal law”. Gramsci observes that this Kantian imperative is "less simple and obvious" as it might seem at first glance (Gramsci 1975a, p. 1484). ${ }^{14}$ Again, he pays attention to something that only apparently is a detail reflecting upon the prepositional locution "in condizioni simili” ("under the same circumstances”), a locution that appears in the Italian translation Gramsci used (or remembered) and that does not figure textually in the German version. Admitting that Gramsci's reference or his memory may have been flawed, one can still see that his thinking has been activated by the little phrase. In the context of translatability/ cultural translation, there is no way not to recognize the existence of diverse cultures ("fundamentally" equal, but different on the surface, or in different historical "phases”), in which the "conditions” are never "the same”. "Everybody acts”, says Gramsci, "according to his own culture, that is to say the culture of his ambience, and 'all men' are for him those of his context, those who think and feel as he does" (ibid.), ${ }^{15}$ in other words: those who share the same common sense.

\footnotetext{
${ }^{12}$ Joseph Buttigieg, the editor of the incomplete American edition of the Prison Notebooks, is planning to translate conpassionalità by "empathy", as he told us on the occasion of the meeting at the School of Oriental and African Studies in London where I had the opportunity to present a first version of this text.

${ }^{13}$ I borrow this musical metaphor from Giorgio Baratta (2008), who for his part developed the notion proposed by Edward Said.

14 “[...] è meno semplice e ovvia di ciò che appare a prima vista”.

15 “Ognuno opera secondo la sua cultura, cioè la cultura del suo ambiente, e 'tutti gli uomini' per lui sono il suo ambiente, quelli che la pensano come lui.”
} 
Can there be a general intelligibility for any imperative? And which is the language/discourse this imperative would have to use? Of course Gramsci claims - as a political hope - that an adequate Marxist language would be the ideal language for such a purpose. ${ }^{16}$ For the time being, it seems to him that such a language is still to be elaborated and that 'translation' has to be constructed case by case - according to the "circumstances" which are "never the same". Consequently, at the end of the paragraph, Gramsci comes to the conclusion that Kant represents an archetypical figure of what he uses to call "cosmopolitan enlightenment”: “Kant's maxim presupposes a single culture, a single religion, a worldwide conformism” (ibid., p. 1484) ${ }^{17}$. In a way, he seems to Gramsci an Esperanto-speaker in ethics: "cosmopolitan" thinkers are for the Sardinian philosopher those who are unable to address people beyond their own social class and who presume to represent universality. Yet, a “world-wide conformism” (cultural uniformity) has never existed, not in Gramsci's time and less in our present condition of accelerated globalization processes, where the local and the global are entangled in processes of mutual construction, as Stuart Hall has famously pointed out.

In the following paragraph Gramsci concludes that even if the "conditions" are "never the same", conditions can also be "created" by the political subject, in order to obtain attention and response from interlocutors, and "creative" means "relative, a way of thinking that modifies the ways of feeling of the majority" (ibid., p. 1486) ${ }^{18}$ - I think that "relative” is here a synonym for "translating”.

In Gramsci’s eyes, ethics, like every other cultural phenomenon, asks for 'translation' processes if the philosopher-legislator pretends to provide a useful guideline for acting in always diverse conditions. Political and humanitarian values have to be 'translated', in order to be understood and negotiated. However, this kind of translation does not mean giving into cultural relativism; according to Gramsci, it rather asks for empathy, containing an affective element, the empathy (con-passionalità) he foregrounds in the famous passage on "living philology”. Con-passionalità does not only mean a caring attitude, but the empathy to feel the other's passions even if they are other passions, such that you would not like to share: not in order to share them at all costs, but to be able to talk to the other, to reach the other.

\footnotetext{
${ }^{16}$ Ibid, p. 1468: "Pare si possa dire appunto che solo nella filosofia della prassi la 'traduzione' è organica e profonda [...]” (my emphasis; translation: “It seems that only in the philosophy of praxis [i.e. Gramsci’s concept of Marxism] 'translation' is organic and profound”).

17 "la massima di Kant presuppone una sola cultura, una sola religione, un conformismo 'mondiale'“.

18 “Creativo occorre intenderlo quindi nel senso di 'relativo', di pensiero che modifica il modo di sentire del maggior numero e quindi della realtà stessa [...]”.
} 
At this point, let us take a step back and consider the question if and where values are addressed in passages of the Prison Notebooks I have discussed so far. Is cultural translation, or its not exact synonym translatability, a candidate for a list of values as some recent theoreticians would have it? In my reading, Gramsci makes it quite clear that it is a tool, an indispensable tool for the good Marxist he wants to educate. But, as a tool, it may be used for different purposes. Let us think just for a moment of commercial uses. When McDonald's offers "Viennese breakfast" in Vienna where there is no lack of charming local coffee houses this may rightly be called a cultural translation in the service of marketing strategies. What makes cultural translation eventually a value is the combination with con-passionalità, an attitude of sharing feelings and passions, and the disposition for non-hierarchical communication. One might object that this is a very vague notion, and indeed it is. Yet the reading of Gramsci's notes on translatability does not provide other insights on the question than just that crucial one: ethics is, for him, bound to the sphere of affections, and translation on its various levels is a tool that - as crucial as it is to mutual understanding - implies choices already made; it is, however, a valuable recognition of difference.

\section{Cultural translation vs. translation as culture}

Finally, I want to confront briefly two recent uses of the concept of cultural translation, Bhabha's and Spivak's. To start with, let me make it clear that the texts I will discuss do not rely on Gramsci; however we can read them in the light of his writings.

The chapter on cultural translation in Bhabha's The Location of Culture is probably the source of many and in my estimation not always adequate uses of the term. I can only roughly summarize my critical points that I have developed in the essay I quoted in the introduction (Wagner 2008). The chapter that deals with the topic, "How newness enters the world", is not a new version of published essays, like other chapters of The Location of Culture, it is a text written for the book and thus arguably of special importance to the author. In his intentionally ambiguous prose, the passage from interlingual translation to cultural translation is never addressed; it seems to be willingly obscured: a fact that has encouraged others to do the same. However, Bhabha works out a definition that is tempting enough: cultural translation as a performative act, as "the staging of difference" (1994, p. 339). This would match St-Paul's concept of the markedness of every translation: its double meaning. But Bhabha remains once again in the realm of ambiguity. On the one hand, he emphasizes with his formula the moment of alterity inherent to all translational acts, on the other hand, his text allows seeing the staging of difference as a characteristic if not prerogative of migrant 
cultures and finally as a definite positive value. With Gramsci we could state that translational practices (understood as cultural translation) are not limited to any particular cultural experience, that they occur between different "phases" of civilization as well as between cultures that are "fundamentally" the same, and that the value is not to be searched in difference itself but in the "con-passionate” way one deals with differences: eventually listening to what the subaltern have to say, without essentializing their way of life. The keyword 'subaltern' leads to the second text I want to discuss briefly, that is Spivak's.

Unlike Bhabha, Spivak is herself a translator. She has not only famously translated Derrida's Of Grammatology (1976), but also several literary texts by the Indian (Bengali) writer Mahasweta Devi. ${ }^{19}$ In a text originally published in 1992, she discusses her work as a translator, among other questions (Spivak 2009). These experiences in the fields of both theory and literature undoubtedly sharpen her vision of the notion of translation on the first, the 'narrow' level. I am discussing in what follows her double essay ${ }^{20}$ "Translation as culture" (2007), and I duly acknowledge the fact that this deliberate choice of terms is not without importance; it seems to express a reserve to the current usages of "cultural translation". The essay starts with a psychoanalytic discussion of the nature of language (the 'birth' of language in early childhood) and hence, the nature of translation which Spivak sees in a kind of continuum with the infant's struggle to 'translate' the outer world. The essay also presents a meditation on the author's personal experiences with the differences of languages, among them differences of standard and idiom: "an unfashionable thing among the elite progressives, without which the abstract structures of democracy cannot be comprehended” (2007, p. 274), and therefore a primary political task. This comes undoubtedly close to Gramsci's thought on translatability (of hegemonic discourses and ethnically/culturally bound common sense), even if she does not quote the texts or even have them in mind at the moment of writing (but Gramsci is not totally absent from her essay since Spivak concludes that she disapproves his being translated "into Indian languages from English", p. 276). It is less the famous impossibility of the subaltern to speak than the scarce subaltern's possibilities to be understood, that seem to concern Spivak here, a preoccupation shared in his time by Gramsci, as I have argued here. When Spivak states that "[n]o speech is speech if it is not heard. It is this act of hearing-to-respond that may be called the imperative to translate" (ibid.), she is once again close to the Sardinian thinker. "[T]he founding translation between people is a

\footnotetext{
${ }^{19}$ Imaginary Maps (1994), Breast Stories (1997), Old Woman (1999), and Chotti Munda and His Arrow (2002).

${ }^{20}$ The essay consists of two parts originally delivered as speeches at Oviedo (Spain) and in New Delhi, where the author received the Translation Award from the National Academy of Letters in India for her work on Mahasweta Devi’s text Imaginary Maps.
} 
listening with care and patience” (ibid.), she continues, matching so - at least in my reading -

Gramsci’s notion of “con-passionality” as a precondition for a valuable translational act. ${ }^{21}$

\section{Works cited}

Bachmann-Medick, Doris (2006): Cultural Turns. Neuorientierung in den

Kulturwissenschaften, Reinbek bei Hamburg: Rowohlt, chapter “Translational Turn”, p. 238-283

Bachmann-Medick, Doris (2009), Introduction: The translational turn, in: Translation Studies 2/1, p. 2-6

Bal, Mieke (2000): Travelling concepts in the humanities: A rough guide, Toronto: Toronto University Press

Baratta, Giorgio (2007): Antonio Gramsci in contrappunto. Dialoghi col presente, Rome: Carocci

Baratta, Giorgio (2008): opening statement in Gramsci ritrovato, special edition of the journal Lares entirely dedicated to Gramsci. Ed. Antonio Deias, Giovanni Mimmo Boninelli, Eugenio Testa (May-August 2008), p. 250-256

Benjamin, Walter (1991): Die Aufgabe des Übersetzers. In: Gesammelte Schriften vol. IV-1, Frankfurt am Main: Suhrkamp, p. 9-21 (first published in 1923). English title: The Task of the Translator

Bhabha, Homi K. (1994): The location of culture. London/ New York: Routledge, chap. "How newness enters the world", p. 212-235

Boothman, Derek (2004a): Traduzione e traducibilità, in: Fabio Frosini/ Guido Liguori ed., Le parole di Gramsci. Per un lessico dei “Quaderni del carcere”, Rome: Carocci, p. 247-266

Boothman, Derek (2004b) Traducibilità e processi traduttivi. Un caso: A. Gramsci, Perugia: Guerra Edizioni

Borghese, Lucia (1981): Tia Alene in bicicletta. Gramsci traduttore dal tedesco e teorico della traduzione, in: Belfagor XXXVI, p. 635-665

Boris Buden/ Stefan Nowotny (2009), Cultural translation: An introduction to the problem, and Responses, in: Translation Studies 2/2, p. 196-219. A further number of responses, including my own, has been published in: Translation Studies 3/1 (2009), p. 94-110.

Gramsci, Antonio (1975a): Quaderni del carcere, 4 vol., ed. Valentino Gerratana, Torino: Einaudi

Gramsci, Antonio (1975b): Lettere dal carcere, ed. Sergio Caprifoglio/ Elsa Fubini, Torino: Einaudi

Gramsci, Antonio (2007): Edizione nazionale degli scritti di Antonio Gramsci. Quaderni del carcere, vol. 1: Quaderni di traduzioni (1919-1932), ed. Giuseppe Cospito/ Gianni Francioni, Istituto della Enciclopedia Italiana

Spivak, Gayatri Chakravorty (2007): Translation as culture, in: Paul St-Pierre/ Prafulla C. Kar ed., In Translation - Reflections, Refractions, Transformations, Amsterdam/ Philadelphia: John Benjamins Publishing Company, p. 263-176

Spivak, Gayatri Chakravorty (2009/2000), The Politics of Translation, in: Lawrence Venuti ed., The Translation Studies Reader. Second Edition, New York and London: Routledge, p.369-388

St-Pierre, Paul (2007): Introduction to St-Pierre/ Kar ed. (2007), p. 1-10

\footnotetext{
${ }^{21}$ I wish to thank Patrick Chapman for his revision of my English text.
} 
Trivedi, Harish (2007): Translating culture vs. cultural translation, in: St-Pierre/ Kar ed. (2007), p. 277-287

Wagner, Birgit (2008): Kulturelle Übersetzung. Erkundungen über ein wanderndes Konzept, on: www.kakanien.ac.at/beitr/postcol. Printed version in: Anna Babka (ed.): Dritte Räume. Homi K. Bhabhas Kulturtheorie. Anwendung. Kritik. Reflexion, Vienna: Turia \& Kant (forthcoming).

\section{Anschrift:}

Prof. Dr. Birgit Wagner

Institut für Romanistik der Universität Wien

Universitätscampus Hof 8

A-1090 Wien

E-Mail: <birgit.wagner@univie.ac.at> 